\title{
Social Psychology: Social or Sociological?
}

\author{
José R. Torregrosa
}

The title of this chapter has definitional connotations. It is generally assumed that definitions are irrelevant as far as the configuration of a field of knowledge is concerned, given that they are merely intentional or wishful statements and can hardly condense the real scope of what a field of knowledge actually is. It is often said that there are as many definitions as the authors who write in any given field. The fact is that definitions are of much more consequence than scientists generally presume (Sapsford, Still, Miell, Stevens, \& Wetherell, 1998). Definitions are what make basic conceptions of a science apparent. They also function as an initial map of the territory encompassed by a field of knowledge. Definitions also legitimize the investigation of certain domains over others. The reader should recognize that to define means to fix limits or boundaries. More generally, at a time of thriving nationalisms, disciplinary nationalism also flourishes. Specifically, boundaries and territoriality are at the root of the struggles and conflicts by which the relative status and power of individuals and groups are shaped. Although these disciplinary struggles are discursive and symbolic, this does not prevent them from being very intense.

The major thrust of my analysis is that social psychology, if it is to become a more representative and conceptually specific discipline, has to be not only social but sociological. The sociological dimension is what provides social psychology its specificity with regard to general or basic psychology. That is, in adopting the perspective of sociology, social psychology thereby becomes a part of sociology as well as psychology. This thesis is the connecting thread for the following arguments and observations. For this purpose I first make some historical references that have had a deep impact on the development of psychological social psychology; second, I evaluate briefly the so-called crisis of social psychology, a turning point with up-to-date consequences; and third, I describe some viewpoints of European and Latin American social psychology, the writings of which seem to go in the direction I am proposing. I end up with some considerations of Kelman's work and intellectual style, focusing on his conception of the discipline and some of his widely influential contributions in expanding the domain of social psychology. 


\section{Historical Antecedents}

The expression social psychology does not seem to have a clear and explicit meaning beyond the realm of the manifold conceptual and methodological traditions in which it is used. The meaning of the term may vary a great deal depending on what is understood by psychology and, above all, on what meaning is ascribed to the term social. On the other hand, what has been the prevalent tendency of academic social psychology would not seem to depart very much from the position maintained by such an influential author as Floyd $\mathrm{H}$. Allport (1924). For him, social psychology is above all psychology and very secondarily social, in whatever way social may be understood. Thus, Allport wrote in a text in which he attempted to specify the basic principles of the field:

There is no psychology of groups which is not essentially and entirely a psychology of individuals. His biological needs are the end toward which his social behavior is a developed means. Within his organism are provided all the mechanisms by which social behavior is explained. (p. 4)

Or, further on in his famous text, Allport wrote:

Social psychology has in fact grown up largely through the labors of the sociologists. It is a mistake, however, to suppose, as some have done, that it is a branch of sociology rather than psychology. . . . In spite of the good offices and interests of the sociologists, the two sciences must remain separate branches of inquiry [italics added]. (p. 11)

It is beyond the scope of this chapter to undertake a detailed analysis of the implications of programmatic texts of this nature. Other authors have provided such analyses with outstanding insight (Cherry, 1995; Danzinger, 1990; Farr, 1996). However, I would like to emphasize a point related to this scientific pronunciamiento that has not yet attracted due attention, at least explicitly. In spite of its obvious conceptual inadequacy and ambiguity, the pronouncement unequivocally conveys a message: Social psychology is exclusively psychology. It is so because it deals with the behavior and consciousness of the individual, albeit in his or her social aspects; malgré tout [in spite of that], social psychology must be psychology alone. To a very large extent, this position has been maintained and reinforced for decades in the various handbooks of social psychology, which contain chapters by influential authors such as Gordon Allport (1954) and Jones (1985) who expressed these views.

Irrespective of the adequacy of F. H. Allport's conceptual framework for both general psychology and social psychology, it seems obvious that the source of confusion induced by definitions such as his rests to a great extent in the meaning attributed to the terms social and social aspects. Even without trying to specify the content of those terms, social psychologists may naively ask if a nonsocial or asocial psychology is feasible. Any human psychology-be it individual or collective-has to deal with "social aspects" and, in that sense, it is "social." The expression social psychology is therefore somehow tautological, as any psychology is social, in one way or another. 
In my opinion, social psychologists will not solve the problem just by stating, as is common practice (even with F. H. Allport), that a psychology is social because it deals with "the social." The subject matter of a science only points to the realm or domain of the reality that it studies or aims to study, but it is not indicative of how it is studied or from what perspective. Paradoxically, social psychology has been very often described as too "individualistic." As Baumeister (1995) has pointed out:

There is a paradox in the way social psychology is practiced today: It isn't always all that social. Ironically, most social psychologists think of people as largely self-contained units, conceding only that occasionally these units come into contact with each other. (p. 75)

Arguments of similar import have been made by authors of different epistemological orientations (Augoustinos, 1999; Marková, 2000; Osterkamp, 1999; Smith, 1999).

If social psychology is basically the extension of the psychological perspective to "the social," then its "individualistic" bias is hardly surprising, given that the level of analysis of psychological theorizing has usually developed around the personality system or its subsystems. The units of analysis of this psychological theorizing are, from the perspective of other social sciences, rather molecular. If one adds to these analytical stipulations the individualistic ethos of Western culture, one can understand Parsons's (1954) observations about general tendencies of psychological theory:

1) Reifying the organism, which by virtue of its genetic constitutions is alleged to provide the "real" basis for the structure of behavior systems; 2) Reifying the "real unit of behavior" which may be either the S-R sequence of the behaviorists, or say the momentary perceptual "gestalt." This then is regarded as the one key to the understanding of all behavior, or; finally, 3) Reifying the individual, the personality in a more or less clearly defined "action" sense. Knowledge of him, independently of his social relationships, current or previous, is alleged to depend on any genuine understanding of how individuals, when put together in societies, will behave. (p. 101)

These observations, made long before social constructionism was fashionable, point not only to the actual difficulties of understanding social behavior by the sole means of the psychological theory in vogue but also to the permanent tension toward a reductionism of "the social" to the individual psychological level or, even further, to the individual biological level. Moscovici (1972) perceptively extended this type of argument to social psychology itself when he attempted to synthesize the implicit assumptions, or postulates, as he calls them, of conventional social psychology:

The first is that the difference between social and elementary non-social processes is only one of degree and that a hierarchy of phenomena can be established in which they are ordered from simpler to more complex, and from individual to collective. The second postulate is that social processes do not imply the existence of social phenomena governed by their laws, but rather 
that they are accounted for by psychological laws, which can at the same time, be based on hypothetical laws of physiology. The final postulate is that there is no difference in kind between social and non-social behaviour: other people intervene only as a part of the general environment. (p. 35)

If the corresponding methodological paradigm of experimentalism is added to these substantive principles, the foundations are laid for establishing the dominant social psychology, as well as for the subsequent counterreactions characteristic of all of the literature that has evolved around the crisis. Such issues are also highlighted in the discipline in what has come to be known as the European social psychology, to which I refer later. More recently, a critical social psychology (Fox \& Prilleltenski, 1997; Ibáñez \& Íñiguez, 1997; Parker \& Spears, 1996; Roger, Stenner, Gleeson, \& Rogers, 1995; Wexler, 1983) has developed that has clear connections with what is supposed to be a postmodern turn in the discipline (Kvale, 1992), whereby truth is problematic and relative to a particular social position, gender, class, or culture (Kendall \& Michael, 1997; Nozick, 2001; Parker, 1998).

These criticisms are usually contested on the grounds that there are at least two social psychologies: one with a psychological orientation and another with a sociological orientation. This distinction implies that both are reductionist with respect to the disciplinary matrix in which they are rooted. In this sense, one might argue that if a psychological bias is noticeable in the psychological social psychology, then there is as well a sociological bias in the sociological social psychology. I believe this type of reciprocal bias argument does not adequately account for the real situation, given that the conceptual framework most representative of sociological social psychology, namely, symbolic interactionism (Mead, 1934), can hardly be labeled "reductionist." Indeed, one of the main achievements of this approach has been to convincingly overcome the old individual-society antinomies, specifying how both realities are constituted through processes of communication and social interaction. This achievement even characterizes the most structural versions, which consider societal norms and roles such as Stryker's (1980) or, in a certain sense, Goffman's (1959).

One of the criticisms that sociologists typically raise against symbolic interactionism is precisely that objective social structure is ignored, thereby reducing sociology to the mentalistic constructions and actions of individuals. On the other hand, I would say that other sociological approaches relevant to social psychology, such as structural-functionalism, which ranges from Parsons (1959) and Inkeles (1963), to Smelser and Smelser (1970), or some of their European colleagues such as Giesen (1987) and Münch (1987), cannot be considered reductionistic. Specifically, their efforts to elucidate the nature of the links between the micro and macro analytical levels-starting with Parsons himself-show their antireductionistic awareness. Also, there have always been "individualistic" traditions within sociological theory that, despite the diversity of their foundations (such as action theory, phenomenology, or exchange theory) exhibit obvious sociopsychological affinities and, in some instances, as in Homans (1967), an explicit psychological reductionism. It would also be difficult to consider such social theorists as Castells (1997), Elias (1987), Giddens (1991), Habermas (1987), or Scheff (1990) as social reductionists when they deal with social psychological problems. Finally, the greater 
institutional, academic-scientific, and professional recognition of psychology has granted this discipline a higher degree of autonomy than is enjoyed by sociology. The consequence is that psychology has had a greater influence on sociology than sociology has had on psychology (House, 1991).

In the light of these considerations and of others of a more ideological nature, I believe that these two social psychologies, psychological and sociological, cannot be put on the same plane with regard to their respective root disciplines and their theoretical and institutional impact on the development of social psychology as a relatively independent field of inquiry.

\section{The Crisis of Social Psychology and Its Metamorphosis}

Regardless of the plausibility of the arguments advanced in the characterization of the discipline from its two main root perspectives, two facts concerning social psychology seem to stand out clearly from the 1950s: On the one hand, we have the hegemonic position of the paradigm of the psychological-individualistic orientation and, on the other, a kind of dissatisfaction aroused by this one-sided hegemony. This dissatisfaction was manifest in the various publications, symposia, and meetings at which social psychologists took stock of the state of the discipline and recommendations were made regarding the necessity of taking into account social variables and the actual context of interaction (e.g., Ring, 1967). The implementation of some "joint programs" by psychology and sociology departments, such as programs at the University of Michigan and Harvard University, might be read as an attempt to bridge the gap between the psychological and sociological leanings. The mid-1960s witnessed their failure in the search for a unitary identity for the discipline as well as the publication of the first texts openly addressing the crisis (Ancona, 1954; Gillin, 1954; Hulett \& Stagner, 1952; Kendler, 1981; McGuire, 1999; Newcomb, 1951, 1954; Rohrer \& Sherif, 1951; Sarason, 1981; Sherif \& Wilson, 1957; Smith, 1974; Tomars, 1957; Westland, 1978).

From the admonitions made by Deutsch and Krauss (1965), Katz (1966), and Ring (1967), to those by Parker and Shotter (1990) or those included in the volume edited by Leary (1989), a substantial amount of literature has accumulated on the frustrating uncertainty and conflict resulting from the nonfulfillment of the scientific advancements predicted by those who, only a few years before, promised great progress, provided that what they considered to be the only truly scientific cannons were strictly observed. Doubts about the consistency, validity, and cumulativeness of scientific findings were raised, as were doubts about their usefulness for the society in which they were produced-not to mention other societies. What started as a matter of internal reflection and debate eventually became an ever-present aspect of any reference dealing with the general problems of the discipline. The confident idea of being on the right path to scientific progress gave way in the 1960s and 1970s to feelings of discouragement and of being at a loss, feelings that were aired frankly by eminent researchers.

In 1963, Berkowitz expressed his confidence about the progressive integration of social psychology within the field of experimental psychology: "Social psychological principles may indeed turn out to be only special cases of more 
general psychological laws" (p. 378). But in 1972, he observed the following to Brewster Smith:

Social psychology is now in a "crisis stage," in the sense that Kuhn used this term in his book The Structure of Scientific Revolutions. We seem to be somewhat at a loss for important problems to investigate and models to employ in our research and theory. It is certainly time to take stock, to see where we are and where we should go. (as cited in Smith, 1972, p. 86)

Moscovici (1972), from the perspective of what at the time was European social psychology, also pointed out the following:

It must be admitted that Social Psychology is not truly a science. We wish to give it an appearance of a science by using mathematical reasoning and the refinements of experimental method; but the fact is that Social Psychology cannot be described as a discipline with a unitary field of interest, a systematic framework of criteria and requirements, a coherent body of knowledge or even a set of common perspectives shared by those who practice it. A solid foundation for the future has not been laid. (p. 32)

A very similar ethos permeates the 1970 s works of many authors (Armistead, 1974; Elms, 1975; Gergen, 1973; Harré \& Secord, 1972; McGuire, 1973; Smith, 1972; Steiner, 1974). Furthermore, the criticisms of Gergen and of Harré and Secord were accompanied by proposals for alternative paradigms. In the 1980s, though less intensely, this ethos also found its advocates (Bar-Tal \& Kruglanski, 1988; Blackler, 1983; Graumann, 1987; Himmelweit \& Gaskell, 1990; Leary, 1989; Parker, 1989; Parker \& Shotter, 1990; Rosnow, 1981). Indeed, one can observe that this kind of questioning, with different nuances and undertones, persists today (Antaki, 2000; Haslam \& McGarty, 2001; Hogg \& Grieve, 1999; House, 1991; Kim, 1999; Kruglanski, 2001; Pancer, 1997; Robinson, 2000; Smith, 2000; Wallach \& Wallach, 1994).

To call this epistemological uneasiness and relative uncertainty the "crisis of social psychology" might be going too far (Ritzer \& Gindoff, 1992). However, if the expression only refers to the psychological social psychology, which adopted the experimental-naturalistic program, then I would say that the word crisis is not an overstatement, given the failure by this group of social psychologists to respond to earlier criticisms of that program. Thus, I conclude that there has been no crisis of social psychology as a whole, but rather a crisis of one of its specific perspectives: the experimental-naturalistic-individualistic paradigm, considered as the only possible way toward scientific progress. Moreover, social psychology has found itself to some extent in a situation of uncertainty and malaise similar to the one that exists in the social sciences in general. For example, in 1970 Gouldner announced "the coming crisis of western sociology," with a frontal critique of the then-hegemonic Parsonian structural-functionalism, and provided the conceptual grounds for a more reflexive sociology that questions its own premises. More recently, to explain the "crisis" in sociology, Levine (1995) has underlined external factors, such as the decreasing availability of resources for research or the loss of prestige and status in society at large, as factors that 
make internal dissent and criticisms more threatening. Horowitz (1993) has emphasized the internal development of unconnected subfields and specialties, with a resulting "decomposition" of the discipline. And Lopreato and Crippen (1999) almost predict the disappearance of sociology as an academic field of knowledge in 25 to 30 years, unless it reconstitutes itself in terms of evolutionary biology.

\section{Viewpoints of European and Latin American Social Psychology}

This debate has had far-reaching consequences in social psychology outside the United States, at least in Europe and Latin America. In this sense the interpretation provided by Moghaddam (1987) is interesting. According to him, the socalled crisis of social psychology was a consequence of the nonacceptance by European and British social psychologists of the dominant conventional social psychology of the first world, that is, North America. His thesis is that, on the one hand, American social psychologists turned their attention toward intradisciplinary metatheoretical and epistemological problems when faced with those criticisms. On the other hand, European social psychologists seemed to believe that they should generate their own distinctive approach rather than follow the agenda and research programs of American social psychology. This focus on affirming differences, preceded by intense and sometimes heated debates, was in itself a clear refutation of the assumed universal validity of the conventional and hegemonic paradigm.

In the same way, Moghaddam (1987) extends this logic when trying to think about the conditions of the development of social psychology in third world countries. These countries cannot uncritically accept the social and psychological knowledge produced in the most industrialized and rich ones, given their different sociocultural, economic, and political problems and interests. As Jahoda (1983) has pointed out, most current theories in experimental social psychology do not seem to be valid or adequate for the social contexts of third world countries. Therefore, social psychologists in these nations need to construct their own social psychology, not because of more or less intense ideological anticolonialistic attitudes, but because of the scientific requirement of a meaningful justification for all steps of the research process, from concept formation to forms of explanation and interpretation of empirical observations.

The issues dealt with in this review may lack significance in a situation where things are back to "business as usual" and a solid institutional base is well established. However, in other sociocultural contexts for which this institutionalization is more recent or still under way, a good occasion is provided to think about the fundamental problems of the discipline and to learn more about the complexities of its emergence and development. Failure to do this leaves the field open to radical and unjust critical deconstructive metaphors. For example, one critic stated, "Psychology--all of it is a branch of the police; psychodynamic and humanistic psychologies are the secret police" (Richer, 1992, p. 118). 
Although talk about the crisis always seems to have negative and problematic connotations, this is not my own attitude. On the contrary, I believe the crisis has had some positive consequences, which are outlined here:

1. Progressive adoption of a philosophical anthropology or a model of humankind more in accordance with humankind's origins and development. When this occurs, the constituent ingredients of humannesssymbolism, language, intentionality, agency, and communicative socialized individuality-not only cease to be strange, but are even considered to be objects of study (Hallowell, 1963; Ibáñez, 1989).

2. An enhanced awareness of temporal specificity or historicity, with respect to the historical condition of the reality that is studied as well as to the psychosociological knowledge itself (Farr, 1990). For example, what can be known about conformity is specific to a given time period.

3. The felt need of rethinking and splitting the linear reconstruction of the historical evolution of social psychology and possible cultural and disciplinary diversification of its history. The criticisms raised about Gordon Allport's (1954) idealized version of "the historical background" of the discipline, leaving aside the problems it may present as an historical interpretation, reopen the question for ongoing investigations of how to establish their historical meaning and their sociocultural anchorage. If those investigations are minimally reflexive or self-critical, researchers will have to rethink their own historical perspective, and, in the last analysis, the definition of its subject matter or the wider tradition in which they are carried out (Graumann, 1987).

4. Greater awareness of the situated character of psychosociological knowledge itself, as an interactively attained construction in specific contexts and for concrete purposes from which it is not possible to sever its contents of truth, that is, to evaluate its plausibility, adequacy, generativity, or relevance. I do not think that this more context-dependent notion of social psychological knowledge should be seen as an uncritical acceptance of a relativistic epistemology; rather, what is called for is a broader conception of explanation than is provided in the conventional hypothetico-deductive framework.

5. Enhanced awareness of the possible ideological functions of social psychology as a provider of categories and methods of interpreting the subjective experience, both individual and collective. Inasmuch as social psychology has also turned its attention onto itself and therefore has reflexively taken into account the social and existential conditions that may influence its concepts, theories, and methods, a greater transparency may be expected in terms of the relationships between social psychological knowledge and power (social, political, or economic). Specifically, social psychologists need to acknowledge how their work may be a specific case of the more general problem of the knowledge-power relationship. One can ask, for instance, to what use is social psychology in areas such as labor-management relations (industrial, postindustrial, and global), human resources policies, organizational functioning, or mass persuasion in political and economic behavior? Is this knowledge a detached and valid reflection of human 
nature or rather a partial account of it, particularly that which is more akin to the dominant ideologies and, therefore, differentially reinforced and accepted, thereby creating in part that human nature as well as explaining it (Heller, 1986; Torregrosa, 1996)?

6. Enhanced acknowledgment of the legitimacy of a genuine epistemicmethodico-technical pluralism, in which the diverse perspectives may enrich research and extend the field of analysis. The laboratory opens up its doors to the "natural" contexts of everyday life (Bar-Tal \& BarTal, 1988; Munné, 1990).

7. A sharper and more critical idea of what constitutes scientific progress and cumulativeness, as distinct from a mechanical result of an unceasing process of data gathering and statistical hypothesis testing. To a large extent, this insight has been possible because the conception of the scientific method-as reconstructed by logical positivism and adopted as a strict (even dogmatic) criterion of what is and is not scientific - has given way to broader conceptions of scientific inquiry in which understanding, intelligibility, and comprehension (i.e., the basis of the hermeneutic-historical paradigm) may be considered as scientific and necessary for the study of human beings as the traditional explanatory-predictive one (Toulmin, 1972). This new philosophy of science seems to narrow the gap between the "two cultures"-that is, the logic of the sciences and the humanitiesproviding epistemic legitimacy to interpretive methodologies, formerly considered, more or less explicitly, to be inadequate for advancing knowledge about the behavior and experience of human beings. As Fay (1996) wrote:

The traditional antagonism between nomologicalism and historicism (with all its attendant oppositions) is ill conceived. Each position is one-sided in itself and requires the other as a supplement to achieve a satisfactory account of understanding human beings. Far from being mutually exclusive, both are required to do justice to the richness of social inquiry. (p. 174)

8. A considerable development toward the applications field, which not only means a differentiation in terms of substantive areas, but also more elaborate conceptions of intervention and practice.

Delineating the preceding issues, in my opinion, has helped to expand what Katz (1978) called the second social psychology (the nonexperimental) and what Himmelweit and Gaskell (1990) have called societal psychology, which is becoming more closely related to the other social sciences.

\section{Toward a More Sociological Social Psychology?}

Underlying these consequences, I seem to perceive a basic strain: the progressive realization of the need to introduce systematically the sociological point of view in conventional social psychology. That is to say, social psychology, in order to be social, cannot carry on being just social; it has to be sociological. To this end, it 
should not attempt to reinvent the psychosociological traditions of sociology (for instance, symbolic interactionism and social structure and personality), but should instead assume them explicitly as inherent parts of itself. This critique implies, therefore, that social psychology is, at the same time, psychology and sociology, and that the adoption of both perspectives in the study of human action and interaction constitutes its analytical specificity as a scientific discipline.

My analysis is consistent with the very significant lines of the so-called European social psychology, as is the case with the volume edited by Himmelweit and Gaskell (1990). The analyses carried out by Gaskell, Farr, Moscovici, Doise, Deutsch, and Himmelweit and published in that volume are quite revealing. Specifically, these authors invoked perspectives rooted in the classical and more up-to-date sources of sociology and other social sciences, expressing and illustrating the need to consider systematically social organization, institutional structures, ideological and axiological structures (social representations and systems of ideas and beliefs), social movements, and the constructive character of social interaction, all of which presuppose the adoption of a sociological point of view-not merely the psychologization of social reality. The importance of adopting a sociological framework becomes particularly evident in Moscovici's (1972) perspective, whereby to show how societies build and presuppose models of individual subjectivity, self-identities, and moral characters, he claims to rely on data in the tradition of sociological thought. I most certainly share this line of argument. Note, however, that what the tradition of sociological thought affords Moscovici is not data but a way of looking at reality or, in other words, a point of view. This distinction is important if sociological perspectives are to be used effectively and explicitly recognized as an intrinsic component of the social psychological perspective itself.

In 1998 Moscovici seemed to reaffirm his advocacy of the "socialization" of social psychology by stating, "The pre-eminence of the social is more and more recognized in the fields of epistemology, language, and social psychology. Personally I am convinced that this is a tendency which will deepen" (p. 212). This call for the adoption of the sociological point of view similarly permeates the work of Himmelweit (1990). When listing the attributes that a societal psychology ought to take into account, Himmelweit included many items that seem to demand a systematic inclusion of approaches that go beyond a conventional psychological perspective. A detailed analysis of each of the propositions that she stated in her proposal would show that research programs that take them into consideration could not readily be carried out while ignoring the sociological perspective. For this reason, as was the case with Moscovici, I think they point in the right direction, overcoming the contradictions that have traditionally hindered social psychology.

However, the comparison that Himmelweit (1990) draws from sociology and the other social sciences with respect to the closeness of their relationship to social psychology does not seem to be either fair or exact. Economics, politics, anthropology, and sociology cannot be placed on the same plane. The degree of generality of the latter two, as Parsons remarked (1951; Parsons et al., 1962), is much higher than in the first two, which only address one of the general dimensions in terms of which it is possible to contemplate the social system. Production 
and distribution occur in the case of economics, whereas power characterizes the case of political science. In moving away from this classificatory exercise in social sciences, what needs to be emphasized is that failing to recognize not only a privileged proximity and affinity between social psychology and sociology, but also a partial identity, would be unfair and, moreover, erroneous, both from the standpoint of a historical reconstruction of the discipline and from an exacting logicalsystematic approach. One would hardly be likely to find a scientific-academic organization around social psychology in other social sciences, apart from psychology, comparable to the existing one in sociology. It is precisely within the specialty of social psychology that sociologists belonging to the American Sociological Association identify most (Ennis, 1992).

When Moscovici (1972) said that it is paradoxical that, in spite of the great acceptance of Mead's (1934) thought over most social sciences, there is an antiMead tendency in social psychology, he expressed only a half-truth. The legacy of Mead's thoughts has continued to the present day as a foundation of the social psychology that is lodged in the disciplinary context of sociology (Joas, 1985; Mead, 1934). To ignore this part of the history and the present day thinking not only implies a biased view of what social psychology has been, is, or should be, but is also rather inconsistent with Moscovici's own tenets. If the two social psychologies must look for ways of coming together and achieving a common identity, as many authors have been postulating for years, then I believe this task calls for an explicit recognition of the fact that both the psychological and sociological points of view ought to be integrated for the sake of the future development of social psychology (House, 1991). The alternative is to follow Allport (1924) and still adhere to the idea that "in spite of the good offices and interests of the sociologists the two sciences must remain separate branches of inquiry" (p. 11). In this case, the perspectives representing contributions and developments of European social psychology, such as those I have just mentioned, would be difficult to implement either in terms of an adequate academic division of labor or in terms of concepts that would establish a clearly distinctive level of analysis. Following Allport's lead would also imply leaving out of the picture the sociological tradition of social psychology (Cook, Fine, \& House, 1995; Lindesmith, Strauss, \& Denzin, 1999).

\section{Conclusion}

Social psychologists have not generally accepted the idea that the two social psychologies should come closer together or merge completely into one single scientific discipline, independent of the two root disciplines, psychology and sociology. For instance, Stryker (1991) argued for the existence and legitimacy of a sociological social psychology. He also maintained that sociology should not be put in the same category as the other social sciences with regard to its relationship with social psychology. Stryker's conceptual strategy is a mixed blessing. On the positive side, it calls for an unrestricted interdisciplinary approach. On the negative side, there is the persistence of those reductionist tendencies that $I$ have been criticizing. This danger was articulated by Parsons (1951): 
There can be no such a thing as a good social psychology without explicit and systematic reference to the sociological aspects of the theory of the social systems. Without that it becomes merely a cover for "psychological bias" in the interpretation of social phenomena. The only alternative to this view is to hold that since all action is "process of the mind" or "behaviour" there is no place for a distinct theory of the social system at all. (p. 553)

This explicitness and systematicity are what I see lacking or even being resisted, at least in the conventional "scientific culture" of European social psychology, whose most representative association marks its distinctive identity with the term experimental: European Association of Experimental Social Psychology. Indeed, this collective self-definition does not seem to lend itself to links with the other social sciences, which can hardly be characterized as experimental in the strict sense of the term. Rather, this self-definition seems to reflect the persistent conflict of the two projects of Psychology as Naturwissenschaft (natural science) or as Geistes-Kulturwissenshaft (cultural science) (Jahoda, 1992; Valsiner \& van der Veer, 2000).

Some similar considerations can be stated with regard to social psychology in Latin America, where several representative authors have demanded a psychology closer to the other social sciences and more sensitive to concrete realities and to the people. For example, it is indicative of this trend when Montero (1990) tried to justify the usefulness of the concept of ideology, in a more or less Marxist sense, or when she wrote that text production "opened the door to new topics, to new perspectives, and to an increasingly perceptible tendency towards a more sociological social psychology, closer to the theories and perspectives of the social sciences . .." but "without sacrificing to them its level of analysis and explanation" (Montero, 1994c, p. 19).

Similar implications can be from Martín-Baró's (1990) elaborations on the same concept of ideology:

Ideology cannot be restricted to a set of ideas and values guiding the life of the person, in a more or less definite way; it must include the system of social forces, which oppress her. . . Obviously, social forces are historical realities; and it is precisely this "historicity," as an intrinsic determinant of behaviour, that is ignored by the dominant psychosocial analyses. (pp. 94-95)

More generally, what Martín-Baró (1998) offered from his critical psychology of liberation is a social psychology oriented toward social change.

The process of inquiry is always rooted in particular social and cultural traditions. Such an inquiry takes the humans beings themselves as its object and, more specifically, humans as social beings. In this context, those cultural traditions are critical and operate as tacit frameworks whereby the questions that social psychologists ask and attempt to answer become meaningfully grounded. Indeed social science itself has to be considered a very important, enlightening, self-reflexive tradition or even more appropriately viewed as a diversity of traditions with their specific national undertones. There are, however, no easy methodological or ideological gambits such as the advocacy of global pseudo-internationalism that will relieve social psychologists of the critical 
task of adequately contextualizing the goals and problems of their research programs (Correa \& Zaiter, 1996). Such efforts (Martín-Baro, 1983, 1989) toward theoretical criticism and reinterpretation of conventional social psychology have helped people to better understand, explain, and eventually change social psychological processes in Central America. From the beginning Martín-Baró made clear the situated perspective of his inquiry: social psychology from Central America. Although they have a more clearly explicit hermeneutical and discourse-analytic orientation, the collective volumes edited by Montero (1991, 1994a, 1994b) have a similar aim.

More recently, other Latin American social psychologists have expressed their intellectual indebtedness when describing their own work. Lane (1999), a Brazilian social psychologist, writes:

In traditional social psychological approaches the human being was fragmented through the use of concepts and particular theories, with the hope held out that sometime in the future it would be possible to unify them. Of the main concepts we reviewed "socialization" was the only one which seemed to have some coherence, for it considered the individual as always inserted in a social context. . . . At this point the work of Martín-Baró was of crucial importance to us. . . . [He] left us a testament, a critical revision of the most important contributions from social psychologists in North America and Europe who were searching for a science that would work on behalf of Caribbean people, and of all Latin Americans. (p. 368)

And Dobles (1999), a Costa Rican social psychologist, said:

Identifying mechanisms by which injustice is legitimized therefore becomes a very important task for a "liberating" psychology. Martín-Baró, who has had such a profound influence in the work of Central American psychologists, wrote about the "deideologization" that psychology had to carry out as major contribution to social justice and the establishment of a real democracy in Latin America as a whole. Specifically, he unmasked many supposed official "truths" in the context of the Salvadorean civil war that had justified foreign intervention and repression by the army. When ... our psychological work serves the purpose of highlighting and working on existing injustices and oppressions, we feel we are indeed travelling on the road indicated by Martín-Baró, with clear Marxist roots, of deideologization. (p. 409)

In view of what I have written up to this point, it is quite plausible to defend the hypothesis I put forward at the beginning of my argument, namely, that social psychology, if it is to be distinctively social, has to be sociological. To me, this viewpoint seems to be a way of looking at the constitutive ambiguities in the history of the field and the tensions and conflicts manifested during its last three decades. This position also reflects a general underlying trend (one that is not explicitly recognized with regard to the epistemological implications for the discipline) in the development of European and Latin American social psychology. It might be argued, however, that this assessment is biased in overstating the role of the sociological perspective and its traditions in the constitution and development of social psychology, although I disagree with this 
argument given the excessively individualistic assumptions of general psychology (Sampson, 1999). Additional support for the view that the advocacy of a more sociological social psychology could lead to a productive reorientation of the discipline can be found in the writing of psychologist Farr (1996), an expert on the history of social psychology:

It is difficult for social psychologists within Psychology . . . to get an adequate appreciation of the distorting effects of the parent discipline. It is prudent to look for other forms of Social Psychology that are not subject to the same distorting influence. There is no need for psychologists to invent new forms of Social Psychology. They already exist-but they do so in disciplines other than Psychology. (p. 131)

This other discipline is, no doubt, sociology. But there is more than one social psychology in sociology: symbolic interactionism (with its diverse developments) and "social structure and personality" or contextual social psychology as Pettigrew (1991) calls it. Searching for a convergence among them and for a more unitary framework with psychological social psychology, Pettigrew has proposed the adoption of Popper's epistemology, which gives more weight to theory construction in the research process than the logical positivist outlook prevailing in experimental social psychology. Though with a different "vision," Kruglanski (2001) has expressed some arguments in the same direction. Following this lead perhaps Popper's "human ontology" should also be taken into account. Because as Popper (1967) has stated:

We have every reason to believe that man or rather his ancestor was social prior to being human (considering, for example, that language presupposes society). But this implies that social institutions, and with them social regularities or sociological laws, must have existed prior to what some people are pleased to call "human nature," and to human psychology. If a reduction is attempted at all, it would therefore be more hopeful to attempt a reduction or interpretation of psychology in terms of sociology than the other way round. (pp. 111-112)

It is clear that the position I have just described is to a large extent coincident with, and indebted to, the one that Herbert Kelman (1965), early in his academic career, outlined in his book International Behavior: A Social-Psychological Analysis, in which he wrote:

Social psychology-which is a subfield of psychology as well as of sociologyis concerned with the intersection between individual behavior and societalinstitutional processes. It follows from this concern that the primary focus for social-psychological analysis is social interaction. (p. 22)

I think that this basic idea of the discipline establishes the framework to which his later intellectual trajectory is linked: a trajectory fruitfully generative of very significant investigations, theoretical and practical.

From an experimental and clinical background, Kelman conceived social psychology in interactionist terms, in accordance with the best theoretical 
traditions of the discipline, explicitly recognizing the needed convergence between psychological and sociological approaches. In line with this conceptual starting point, it can be said that his work as a whole may be characterized by an interdisciplinary openness that makes clear the deep need for unity of the social sciences, particularly when faced with having to account for complex social phenomena, a situation in which the conceptual frameworks of specific disciplines show their insufficiency. It is this openness and a rigorous style of thinking that allow for the smooth transition between concrete empirical research and a conscious framework of values from which a meaning can be ascribed to research. In this way, as Berlin (1992) has said, "social science knowledge may become ethical wisdom" (p. 22).

With regard to the epistemological disputes that have been taking place in the discipline, and to which I have referred earlier, Kelman has maintained an attitude far away from any methodological dogmatism. Kelman's approach is not an easy or expeditious eclecticism but rather a way of looking at human affairs with the awareness of the complexity of human nature. Furthermore, in unraveling this complexity, Kelman relies more on adequacy, sensibility, and precision of concepts than on methodological and technical virtuosity. Through his investigations, we can observe the primacy of the theoretical moment, the effort at conceptual clarification and construction, and the search for plausible intelligibility. He uses this mode of analysis in those contexts in which the objective is application or the production of change as well as in conflict resolution workshops to improve Palestinian-Israeli relations at both personal and policy levels (Kelman, 1983). These interventions may be taken as instances of the following well-known Lewinian (Lewin, 1964) statement:

Many psychologists working today in an applied field are keenly aware of the
need for close cooperation between theoretical and applied psychology. This
can be accomplished ... if the theorist does not look toward applied prob-
lems with highbrow aversion or with a fear of social problems, and if the
applied psychologist realizes that there is nothing so practical as a good the-
ory. (p. 169)

Kelman's already classical model of social influence processes has been an alternative approach in the study of attitudes to the more traditional individualistic perspectives of cognitivism. By specifying the motivational bases of attitudes, these processes were anchored more deeply in the personality structure, and the means to induce their change were made explicit. By linking attitude change to specific processes of interaction, the concept of attitude becomes more similar to the meaning with which it is used in the other traditions of the social sciences, as in the theory of social action or the sociology of knowledge. The analytic usefulness of the concept of attitude can then be extended from individual to collective subjectivity. In a certain sense, this type of meaning is what European social psychologists have attempted to convey by the concept of social representations.

In Kelman's study with Hamilton on criminal obedience to authority (Kelman \& Hamilton, 1989), the focus is as much on the types of social relationships and their organizational contexts as on the intrapersonal processes of 
individuals participating in them. This approach, within the frame of Kelman's theory of social influence, allows for the systematic consideration of power, with its correlates such as ideology, interests, and social organization. Destructive or criminal obedient behavior becomes not only the outcome of perverse or irrational dispositions of human nature, but also the way in which people structure their hierarchical relations and the beliefs and the ideologies that legitimate them, as Kelman and Hamilton (1989) wrote:

The occurrence of sanctioned massacres cannot be adequately explained by the existence of psychological forces-whether these be psychological dispositions to engage in murderous violence or profound hostility against the target-so powerful that they must find expression in violent acts unhampered by moral restraints. Instead, the major instigators for this class of violence derive from the policy process. (p. 15)

These references to the work of Herbert Kelman as well as his explicit recognition of the role of power inequalities in Palestinian-Israeli relations clearly show that his research endeavors and conceptual framework are not confined to the limits of psychological social psychology. Kelman's work can be considered an influential and respected paradigmatic model in which psychological and sociological levels of analysis are meaningfully related.

\section{References}

Allport, F. H. (1924). Social psychology. Boston: Houghton-Mifflin.

Allport, G. (1954). The historical background of modern social psychology. In G. Lindzey (Ed.), The handbook of social psychology (Vol. 1, pp. 3-56). Reading, MA: Addison-Wesley.

Ancona, L. (1954). La psicologia sociale negli Stati Uniti d'America [Social psychology in the United States of America]. Milano: Soc. Editrice "Vita e Pensiero."

Antaki, C. (2000). Simulation versus the thing itself: Commentary on Markman and Tetlock. British Journal of Social Psychology, 39, 327-331.

Armistead, N. (Ed.). (1974). Reconstructing social psychology. Harmondsworth, England: Penguin.

Augoustinos, M. (1999). Ideology, false consciousness and psychology. Theory and Psychology, 9, 295-312.

Bar-Tal, D., \& Bar-Tal, Y. (1988). A new perspective of social psychology. In D. Bar-Tal \& A. W. Kruglanski (Eds.), The social psychology of knowledge (pp. 83-108). Cambridge, England: Cambridge University Press.

Bar-Tal, D., \& Kruglanski, A. W. (Eds.). (1988). The social psychology of knowledge. Cambridge, England: Cambridge University Press.

Baumeister, R. F. (1995). The personal story of an interpersonal psychologist. In G. G. Brannigan \& M. R. Merrens (Eds.), The social psychologists: Research adventures (pp. 75-96). New York: McGraw-Hill.

Berkowitz, L. (1963). Social psychological theorizing. In G. Marx (Ed.), Theories in contemporary psychology (pp. 369-388). New York: Macmillan.

Berlin, I. (1992). El fuste torcido de la humanidad [The crooked timber of humanity]. Barcelona, Spain: Ediciones Península. (Original work published 1959)

Blackler, F. (Ed.). (1983). Social psychology and developing countries. New York: Wiley.

Castells, M. (1997). The information age: Economy, society, and culture (Vol. 2). Cambridge, MA: Blackwell.

Cherry, F. (1995). The "stubborn particulars" of social psychology. London: Routledge. 
Cook, K. S., Fine, G. A., \& House, J. S. (Eds.). (1995). Sociological perspectives on social psychology. Boston: Allyn \& Bacon.

Correa, N., \& Zaiter, J. (1996). Problemas de aplicación e intervención en psicología social [Application and intervention problems in social psychology]. In J. L. Álvaro, A. Garrido, \& J. R. Torregrosa (Eds.), Psicología social aplicada [Applied social psychology] (pp. 511-517). Madrid, Spain: McGraw-Hill.

Danzinger, K. (1990). Constructing the subject: Historical origins of psychological research. Cambridge, England: Cambridge University Press.

Deutsch, M., \& Krauss, R. H. (1965). Theories in social psychology. New York: Basic Books.

Dobles, I. (1999). Marxism, ideology and psychology. Theory and Psychology, 9, 407-410.

Elias, N. (1987). El proceso de la civilización: Investigaciones sociogenéticas y psicogenéticas [The civilization process: Sociogenetic and psychogenetic investigations]. México City: Fondo de Cultura Económica.

Elms, A. C. (1975). The crisis of confidence in social psychology. American Psychologist, 30, 967976.

Ennis, J. G. (1992). The social organization of sociological knowledge: Modeling the intersection of specialties. American Sociological Review, 57, 259-265.

Farr, R. (1990). Waxing and waning of interest in societal psychology: A historical perspective. In H. T. Himmelweit \& G. Gaskell (Eds.), Societal psychology (pp. 46-65). London: Sage.

Farr, R. (1996). The roots of modern social psychology. Cambridge, England: Blackwell.

Fay, B. (1996). Contemporary philosophy of social science. Oxford, England: Blackwell.

Fox, D., \& Prilleltenski, I. (Eds.). (1997). Critical psychology: An introduction. London: Sage.

Gergen, K. (1973). Social psychology as history. Journal of Personality and Social Psychology, 26, $309-320$.

Giddens, A. (1991). Modernity and self-identity: Self and society in late modern age. Stanford, CA: Stanford University Press.

Giesen, B. (1987). Beyond reductionism: Four models relating micro and macro levels. In J. C. Alexander, B. Giesen, R. Münch, \& N. J. Smelser (Eds.), The micro-macro link (pp. 337-355). Berkeley: University of California Press.

Gillin, J. (Ed.). (1954). For a science of social man. New York: Macmillan.

Goffman, E. (1959). The presentation of self in everyday life. Garden City, NY: Doubleday Anchor Books.

Gouldner, A. (1970). The coming crisis of Western sociology. New York: Basic Books.

Graumann, C. F. (1987). History as multiple reconstruction: Of mainstreams, tributaries, and undercurrents. In G. R. Semin \& B. Krahe (Eds.), Issues in contemporary German social psychology (pp. 1-15). New York: Springer-Verlag.

Habermas, J. (1987). Teoría de la acción comunicativa [Theory of communicative action]. Madrid, Spain: Editorial Taurus.

Hallowell, A. I. (1963). Personality, culture, and society in behavioral evolution. In S. Koch (Ed.), Psychology: A study of a science (Vol. 6, pp. 429-509). New York: McGraw-Hill.

Harré, R., \& Secord, P. F. (1972). The explanation of social behaviour. Oxford, England: Blackwell.

Haslam, S. A., \& McGarty, C. (2001). A 100 years of certitude? Social psychology, the experimental method and the management of scientific uncertainty. British Journal of Social Psychology, 40, 1-21.

Heller, F. (Ed.). (1986). The use and abuse of social science. London: Sage.

Himmelweit, H. T. (1990). Societal psychology: Implications and scope. In H. T. Himmelweit \& G. Gaskell (Eds.), Societal psychology (pp. 17-45). London: Sage.

Himmelweit, H. T., \& Gaskell G. (Eds.). (1990). Societal psychology. London: Sage.

Hogg, M. A., \& Grieve, P. (1999). Social identity theory and the crisis of confidence in social psychology: A commentary, and some research on uncertainty. Asian Journal of Social Psychology, 2, $79-93$.

Homans, G. C. (1967). The nature of social science. New York: Harcourt, Brace \& World.

Horowitz, I. L. (1993). The decomposition of sociology. New York: Oxford University Press.

House, J. S. (1991). Sociology, psychology, and social psychology (and social science). In C. W. Stephan, W. G. Stephan, \& T. F. Pettigrew (Eds.), The future of social psychology (pp. 45-60). New York: Springer-Verlag. 
Hulett, J. E., \& Stagner, R. (Eds.) (1952). Problems in social psychology: An interdisciplinary inquiry. Urbana: University of Illinois Press.

Ibáñez, T. (Ed.). (1989). El conocimiento de la realidad social [The knowledge of social reality]. Barcelona, Spain: Sendai.

Ibáñez, T., \& Íniguez, L. (Eds.). (1997). Critical social psychology. London: Sage.

Inkeles, A. (1963). Sociology and psychology. In S. Koch (Ed.), Psychology: A study of a science (Vol. 6, pp. 317-387). New York: McGraw-Hill.

Jahoda, G. (1983). Has social psychology a distinctive contribution to make? In F. Blackler (Ed.), Social psychology in developing countries (pp. 25-31). New York: Wiley.

Jahoda, G. (1992). Crossroads between culture and mind: Continuities and change in theories of human nature. New York: Harvester-Wheatsheaf.

Joas, H. (1985). George Herbert Mead: A contemporary re-examination of his thought. Cambridge, England: Polity Press.

Jones, E. E. (1985). Major developments in social psychology during the past five decades. In G. Lindzey \& E. Aronson (Eds.), The handbook of social psychology (3rd ed., Vol. 1, pp. 1-46). New York: Random House.

Katz, D. (1966). Editorial. Journal of Personality and Social Psychology, 7, 341-344.

Katz, D. (1978). Social psychology in relation to the social sciences: The second social psychology. American Behavioral Scientist, 21, 779-792.

Kelman, H. C. (Ed.). (1965). International behavior: A social-psychological analysis. New York: Holt, Rinehart \& Winston.

Kelman, H. C. (1983). Nacionalismo e identidad nacional: Un análisis psicosocial [Nationalism and national identity: A social psychological analysis]. In J. R. Torregrosa \& B. Sarabia (Eds.), Perspectivas y contextos de la psicología social [Perspectives and contexts of social psychology] (pp. 241-268). Barcelona, Spain: Editorial Hispanoeuropea.

Kelman, H. C., \& Hamilton, V. L. (1989). Crimes of obedience: Toward a social psychology of authority and responsibility. New Haven, CT: Yale University Press.

Kendall, G., \& Michael, M. (1997). Politicizing the politics of postmodern social psychology. Theory and Psychology, 7, 7-29.

Kendler, H. H. (1981). Psychology: A science in conflict. New York: Oxford University Press.

Kim, U. (1999). After the "crisis" in social psychology: The development of the transactional model of science. Asian Journal of Social Psychology, 2, 1-19.

Kruglanski, A. W. (2001). That "vision thing": The state of theory in social and personality psychology at the edge of the new millennium. Journal of Personality and Social Psychology, 80, 871875.

Kvale, S. (1992). Psychology and postmodernism. London: Sage.

Lane, S. T. M. (1999). Ideology and consciousness. Theory and Psychology, 9, 367-378.

Leary, M. R. (1989). The state of social psychology. London: Sage.

Levine, D. N. (1995). Visions of the sociological tradition. Chicago: University of Chicago Press.

Lewin, K. (1964). Field theory in social science: Selected papers (D. Cartwright, Ed.). New York: Harper Torchbooks. (Original work published 1944)

Lindesmith, A. R., Strauss, A. L., \& Denzin, N. K. (1999). Social psychology (8th ed.). Thousand Oaks, CA: Sage.

Lopreato, J., \& Crippen, T. (1999). Crisis in sociology: The need for Darwin. New Brunswick, NJ: Transaction.

Marková, I. (2000). The individual and society in psychological theory. Theory and Psychology, 10, $107-116$.

Martín-Baró, J. I. (1983). Acción e ideología: Psicología social desde Centroamérica [Action and ideology: Social psychology from Central America]. San Salvador, El Salvador: UCA Eds.

Martín-Baró, J. I. (1989). Sistema, grupo y poder: Psicología social desde Centroamérica [System, group, and power: Social psychology from Central America]. San Salvador, El Salvador: UCA Eds.

Martín-Baró, J. I. (1990). Religion as an instrument of psychological warfare. Journal of Social Issues, 46(3), 93-107.

Martín-Baró, J. I. (1998). Psicología de la liberación [Psychology of liberation]. Madrid, Spain: Trotta. 
McGuire, W. J. (1973). The yin and yang of progress in social psychology: Seven koan. Journal of Personality and Social Psychology, 26, 446-456.

McGuire, W. J. (1999). Constructing social psychology. Cambridge, England: Cambridge University Press.

Mead, G. H. (1934). Mind, self, and society: From the standpoint of a social behaviorist (C. Morris, Ed.). Chicago: The University of Chicago Press.

Moghaddam, F. M. (1987). Psychology in three worlds: As reflected by the crisis in social psychology and the move towards indigenous third-world psychology. American Psychologist, 42, 912-920.

Montero, M. (1990). Ideology and psychosocial research in third world contexts. Journal of Social Issues, 46(3), 43-45.

Montero, M. (Ed.). (1991). Acción y discurso: Problemas de psicología política en América Latina [Action and discourse: Problems of political psychology in Latin America]. Caracas, Venezuela: Eduven.

Montero, M. (Ed.). (1994a). Construcción y crítica de la psicología social [Construction and critique of social psychology]. Barcelona, Spain: Anthropos.

Montero, M. (Ed.). (1994b). Psicología social comunitaria [Community social psychology]. Jalisco, Mexico: Publicaciones de la Universidad de Guadalajara.

Montero, M. (1994c). La psicología social en la América Latina [Social psychology in Latin America]. Anthropos, Issue 156, pp. 17-23.

Moscovici, S. (1972). Society and theory in social psychology. In J. Israel \& H. Tajfel (Eds.), The context of social psychology: A critical assessment (pp. 17-68). London: Academic Press.

Moscovici, S. (1998). The history and actuality of social representations. In U. Flick (Ed.), Defining the social (pp. 209-273). Cambridge, England: Cambridge University Press.

Münch, R. (1987). The interpenetration of microinteraction and macrostructures in a complex and contingent institutional order. In J. C. Alexander, B. Giesen, R. Münch, \& N. J. Smelser (Eds.), The micro-macro link (pp. 319-336). Berkeley: University of California Press.

Munné, F. (1990). Entre el individuo y la sociedad [Between the individual and society]. Barcelona, Spain: PPU.

Newcomb, T. H. (1951). Social psychological theory: Integrating individual and social approaches. In J. Rohrer \& M. Sherif (Eds.), Social psychology at the crossroads (pp. 31-49). New York: Harper \& Row.

Newcomb, T. H. (1954). Sociology and psychology. In J. Gillin (Ed.), For a science of social man (pp. 227-256). New York: Macmillan.

Nozick, R. (2001). Invariances: The structure of the objective world. Cambridge, MA: Belknap Press of Harvard University Press.

Osterkamp, U. (1999). On psychology, ideology and individual's societal nature. Theory and Psychology, 9, 379-392.

Pancer, S. M. (1997). Social psychology: The crisis continues. In D. Fox \& I. Prilleltenski (Eds.), Critical psychology: An introduction (pp. 150-165). London: Sage.

Parker, I. (1989). The crisis in modern social psychology and how to end it. London: Routledge.

Parker, I. (1998). Against postmodernism: Psychology in cultural context. Theory and Psychology, 8, 601-627.

Parker, I., \& Shotter, J. (Eds.). (1990). Deconstructing social psychology. London: Routledge.

Parker, I., \& Spears, R. (Eds.). (1996). Psychology and society: Radical theory and practice. London: Pluto Press.

Parsons, T. (1951). The social system. Glencoe, IL: Free Press.

Parsons, T. (1954). Psychology and sociology. In J. Gillin (Ed.), For a science of social man (pp. 67101). New York: Macmillan.

Parsons, T. (1959). An approach to psychological theory in terms of the theory of action. In S. Koch (Ed.), Psychology: A study of a science (Vol. 3, pp. 612-723). New York: McGraw-Hill.

Parsons, T., Shils, E. A., Allport, G. W., Kluckhohn, C., Murray, H. A., Sears, R. R., et al. (1962). Some fundamental categories of the theory of action: A general statement. In T. Parsons \& $\mathbf{E}$. Shils (Eds.), Toward a general theory of action (pp. 3-29). New York: Harper Torchbooks. (Original work published 1951)

Pettigrew, T. F. (1991). Toward unity and bold theory: Popperian suggestions for two persistent problems of social psychology. In C. W. Stephan, W. G. Stephan, \& T. F. Pettigrew (Eds.), The future of social psychology (pp. 13-27). New York: Springer-Verlag. 
Popper, K. (1967). La sociedad abierta y sus enemigos [The open society and its enemies]. Buenos Aires: Paids. (Original work published 1945)

Richer, P. (1992). An introduction to deconstructionist psychology. In S. Kvale (Ed.), Psychology and postmodernism (pp. 110-118). London: Sage.

Ring, K. (1967). Experimental social psychology: Some sober question about some frivolous values. Journal of Experimental Social Psychology, 3, 113-123.

Ritzer, G., \& Gindoff, P. (1992). Methodological relationism: Lessons for and from social psychology. Social Psychology Quarterly, 2, 128-140.

Robinson, D. N. (2000). Paradigms and "the myth of the framework": How science progresses. Theory and Psychology, 10, 39-47.

Roger, R. S., Stenner, P., Gleeson, K., \& Rogers, W. S. (1995). Social psychology: A critical agenda. Cambridge, England: Polity Press.

Rohrer, J., \& Sherif, M. (Eds.). (1951). Social psychology at the crossroads. New York: Harper.

Rosnow, R. L. (1981). Paradigms in transition. New York: Oxford University Press.

Sampson, E. E. (1999). Liberating psychology. In La psicologia al fin del siglo [Psychology at the end of the century] (pp. 305-321). Caracas, Venezuela: Sociedad Interamericana de Psicologia.

Sapsford, R., Still, A., Miell, D., Stevens, R., \& Wetherell, M. (Eds.). (1998). Theory and social psychology. London: Sage.

Sarason, S. B. (1981). Psychology misdirected. New York: Free Press.

Scheff, T. J. (1990). Microsociology: Discourse, emotion, and social structure. Chicago: University of Chicago Press.

Sherif, M., \& Wilson, M. O. (Eds.). (1957). Emerging problems in social psychology. Norman: University of Oklahoma Book Exchange.

Smelser, N. J., \& Smelser, W. T. (Eds.). (1970). Personality and social systems. New York: Wiley.

Smith, J. L. (2000). The psychology of action. New York: St. Martin's Press.

Smith, M. B. (1972). Is experimental social psychology advancing? Journal of Experimental Social Psychology, 8, 86-96.

Smith, M. B. (1974). Humanizing social psychology. San Francisco: Jossey-Bass.

Smith, R. J. (1999). Social/personality psychology in context. Theory and Psychology, 9, 769-786.

Steiner, I. D. (1974). Whatever happened to the group in social psychology? Journal of Experimental Social Psychology, 10, 94-108.

Stryker, S. (1980). Symbolic interactionism: A social structural approach. Menlo Park, CA: Benjamin-Cummings.

Stryker, S. (1991). Consequences of the gap between "the two social psychologies." In C. W. Stephan, W. G. Stephan, \& T. F. Pettigrew (Eds.), The future of social psychology (pp. 83-97). New York: Springer-Verlag.

Tomars, A. S. (1957). Sociology and interdisciplinary developments. In H. Becker \& A. Boskoff (Eds.), Modern sociological theory (pp. 501-527). New York: Holt.

Torregrosa, J. R. (1996). Concepciones del aplicar [Conceptions about applying]. In J. L. Alvaro, A. Garrido, \& J. R. Torregrosa (Eds.), Psicología social aplicada [Applied social psychology] (pp. 39-56). Madrid, Spain: McGraw-Hill.

Toulmin, S. (1972). Human understanding: The collective use and evolution of concepts. Princeton, NJ: Princeton University Press.

Valsiner, J., \& van der Veer, R. (2000). The social mind: Construction of the idea. Cambridge, England: Cambridge University Press.

Wallach, L., \& Wallach, M. A. (1994). Gergen versus the mainstream: Are hypotheses in social psychology subject to empirical test? Journal of Personality and Social Psychology, 67, 233-242.

Westland, G. (1978). Current crises of psychology. London: Heinemann.

Wexler, P. (1983). Critical social psychology. London: Routledge. 